\title{
Abstract title index
}

World Federation of Critical Care Nurses, World Congress, Florence, Italy, 2009.

Web site: http://en.wfccn.org

Key words: abstracts * critcal care * index * nursing * titles *WFCCN *

\section{ENGLISH ABSTRACTS} B

A

A global comparative analysis of relatives' visiting practices within ICU T Collins, C Plowright; 148

A pilot study of sound levels in an Australian adult general intensive care unit

R Elliott, S McKinley, D Eager, S Ladanyi; 150

A water overload treatment in ICU with peripheral veno-venous approach: a new minimally invasive technique

P Celotti, A De Monte, L Peressoni, A Zanetti; 144

Activities undertaken by registered nurses in the ICU: a work sampling observational study

M Foster, N Murphy, W Chaboyer; 152

Adverse events at the ICU: nurses' perception on the non-punishment culture (poster)

K Grillo Padilha, C Claro, DC Krokoscz, MC Toffolleto; 155

Ahead of local time: preparing Macedonian nurses for state of the art ICU

T Pampel; 166

An evaluation of the outreach teams in the UK and the ICU Liaison teams in Australia

A Green; 153

Application of NANDA, NIC in postoperative of cardiovascular surgery in Peru (poster)

P Chauca, R Gonzales; 145

Are our patients enough aware of warfarin therapy?

T Sengul, U Sipahi, A Yilmaz; 173
Being the nurse for a decerebrate patient: a phenomenological study H Cicek, A Demirtas, N Tosun, A Yava, CT Ozcan, N Akbayrak; 147

Binational mentor program for intensive care research coordinators-results of an audit of the utilisation (poster) B Curwood, S O'Connor, J Chamberlain, K Marsden, J Mehrtens, D Rajbhandari, M Tallot, J Thomas; 149

Black Saturday

M Pacquola, N Adams, H Menezes; 166

Booming and blooming: meeting diverse needs and population growth with practice development in Dubai M Fielding; 152

C

Clinical effect of emergent percutaneous intervention on inhospital mortality of octogenarian with acute myocardial infarction admitted to coronary care unit (poster) E Shin, MH Jeong, MW Yeo, SH Lee, ES Lee; 174

Comparing two different methods for measuring cardiac output (poster) R Parke, J Beca, P Reed, S McGuinness, R Patel, B Kent; 168

\section{Conflict management in ICU \\ V Dumbovic; 150}

Cost-benefit analysis of an ICU psychosis prevention strategy EH Lee, SA Park, JH Kim; 160

CQI strategies for reducing the incidence of unplanned endotracheal extubation in an ICU (poster)

S Chen; 145
Creating a discharge plan for IVAD patient intended to community setting N Shnaider, I Ribakovsky, Y Boykis, Y Nigel; 175

Critical care nurse development requires support beyond the acquisition of clinical knowledge

T Moylan, J Watterson, S Brack; 164

Critical care nurses' perceptions of endof-life care and their nursing practice in Japan (poster)

A Yamada, E Takamizawa, K Mori; 180

Critical care nursing course in Turkey (poster)

O Yazici Korkmaz, E Turkmen, S Abali, S Balci; 182

Determining standard criteria for endotracheal suctioning in the paediatric intensive care patient K Davies, L Monterosso, GD Leslie; 149

Development of organization A Friganovic, V Dumbovic; 153

Development of postgraduate level competencies for critical care nurses M Hadjibalassi, E Papastavrou, A Merkouris, E Lambrinou, E Athini, E Georgiou, E Nicolaou; 154

Development of trauma nursing competency standards in ICU C Birch, J Watterson; 141

Dichlorvos- and methomyl-induced respiratory toxicity results from central muscarinic effects (poster) F Baud, P Houze, G Levy, A David; 141

Difficulties in practicing end-of-life care of nurses and their efforts to deal with (poster)

Y Itojima, H Takaoka, N Sakata; 157 
Do patients demand immediate discharge from the cardiology ICU? (poster)

A Demirtas, $\mathrm{H}$ Cicek, A Yava, N Tosun, N Akbayrak, CT Ozcan; 150

E

Effective discharge and handover from ICU (poster)

L Retallick, L Massey; 172

Effective ICU patient allocation processes results in optimal patient care and staff satisfaction

S Brack, S O'Brien; 142

Effects of standardized oral care protocol and disposable ventilator circuit on the reduction of ventilatorassociated pneumonia and nosocomial infection among ICU patients (poster) E Shin, MY Yeo, MH Jeong, SY Hwang, ES Lee; 174

Efficacy of subglottic secretion drainage with a multilumen endotracheal tube P Young, D Reid, A Fletcher, J Carter, M Blunt; 182

Errors in health care and the patient safety - analysis of transcription process MJ Landeiro; 160

Europe: Levels Of Intensive-Care Nurses' Knowledge Survey (E-LINKS)

P Fulbrook, J Albarran, B Baktoft, B

Sidebottom; 153

Evaluate the success and failure of early extubation in COPD patients after completion of bariatric (poster) E Zampier, PM Ono, SH Mendes, NF Serr; 183

Evaluation of deaths occurred in a University Hospital (poster)

R Moritz, F Machado; 164

Evidence to practice - shifting what we know to what we do in the PICU

M Coetzee, C Bonaconsa; 148

\section{F}

Factors affecting on family members' anxiety at the time of transfer from ICU (poster)

HK Kwon, MS Song; 159

Family members successfully partner with nurses to provide fundamental care for patients in ICU

M Mitchell, W Chaboyer, M Foster; 164
H

Haemodynamic effect of administrating lebosimentanis in patients with low cardiac output

A Kouimtzoglou, A Margazas, S Diplou, A Antoniou: 158

Health outcomes of children with traumatic injuries: a linked data project A Ramelet, J Finn, S Erickson, A Duncan, K Langdon, G Geelhoed; 172

Hemodynamic and physiologic monitor during postural change after CABG predicted short term outcomes (poster) Y Hui Tzu; 156

Hemodynamic changes during the bed bath: a pilot study (poster)

AF Miranda, MB Goncalves, O Petrucci, AG Tocina; 163

How do intensive care patients' respond to painful initiatives? (poster) F Eti Aslan, S Karadag Arli, M Yavuz, I Aytacoglu, K Temiz, E Cinar, S Purisa; 152

I

ICU follow-up services: an Italian national survey

M Solaro, L Migliaccio, A Peris, JA Griffiths, G Becattini, S Bambi; 175

Improving clinical communication and patient safety in ICU: the HELiCS initiative

D Rajbhandari, R ledema, E Merrick, R Herkes, M Lucey; 170

Incidence of atrial fibrillation in patients after aortic or mitral valve replacement E Liapi; 161

Influence of leadership styles on leadership effectiveness: the perspective of registered nurses (poster) S Chi; 146

Influence of nursing workload on catheter-related bloodstream infection in a critical care unit (poster)

A Jara Perez, FJ Carmona Monge, M

Martinez Lareo, G Rollan Rodriguez,

Cerrillo Gonzalez, S Garcia Gomez, C Quiros

Herranz, R Alameda Varela, R Ruiz de Luna, A

Algora Weber; 157

Influences of night time nursing interventions upon sleep of healthy volunteers in simulated ICU (poster) N Hirakawa, Y Ikematsu; 156
Innovations in seating for patients in the ICU

T Williams, GD Leslie, R Bingham, L Brearley; 180

Innovative critical care education: building confidence through high fidelity simulation

S Goldsworthy, L Graham; 154

Introducing electronic journey boards to ICU (poster)

J Jennings, K Clark, P Donaldson; 158

Investigation of respiratory flora in cardiologic patients after endotracheal intubation (poster)

A Spirou, G Saroglou, Z Aggelopoulou; 176

Irukandji Jellyfish envenomation: recognition and nursing management K Poulish, B Simmonds; 170

Is the neck pillow effective against the positional neck pain in patients undergoing cardiac surgery? (poster) A Koyuncu, A Yava, F Koyuncu, M Kurkluoglu, U Demirkilic; 159

Isolation recommendation and standards in adult ICU of Turku University Hospital, Finland (poster) N Kallio, J Lehtinen, T Peltokangas, T Joutsalainen; 158

Keeping ICU nurses away from exhaustion (poster)

H Cicek, A Yava, N Tosun, CT Ozcan, A Demirtas, N Akbayrak; 147

Knowledge and attitudes of cardiology and cardiovascular surgery nurses about pain management

A Yava, A Koyuncu, N Tosun, H Cicek, B Dizer; 182

Knowledge and management of tracheal tube cuffs among nurses of ICU in Korea (poster)

S Chang, M Song; 144

$\mathbf{L}$

Leadership competencies and influencing factors perceived by Indian critical care unit nurse managers (poster)

J Vati, A Nafra, M Sharma; 178

Life saving facilities: a new modern hospital in Western Africa (poster) Z Zohar, Y Rubin, A Stamler; 183 
Living with non-invasive ventilation at home: patients' perspectives and experience

F Bastos, A Silva; 140

Local experience with the use of bubble CPAP in infants with bronchiolitis: a

4-year follow-up study

K Mills, J Smith, A Pirret; 162

\section{M}

Mapping delirium assessment in Australian and New Zealand ICU S Eliott, R Mistarz, A Whitfield, D Ernest; 151

Medical students' narratives on nonverbal communication in a paediatric ICU

LM Vivian, A McKay, N Msimeki; 179

Meta-analysis of the effectiveness of psychological support for the improvement of coronary heart Z Aggelopoulou; 139

Moral distress in Hellenic ICU nurses and associations with autonomy and collaboration

E Papathanassoglou, S Haikali, M Kalafati, M Karanikola, M Giannakopoulou, C Lemonidou 167

$\mathbf{N}$

Needlestick and sharp injuries among ICU nurses

S Samancioglu, A Durmaz Akyol, D Unlu, E Saban; 172

Nurses' perceptions and knowledge of tight glycemic control

R Alameda Varela, C Quiros Herranz,

S Garcia Gomez, M Martinez Lareo, FJ

Carmona Monge, A Jara Perez, G Rollan, I

Cerrillo Gonzalez; 139

Nursing activities score in Norway

S Stafseth; 176

Nursing clinical supervision in the professional training

R Pires, AM Pires; 168

Nursing educational strategies for the management of heart failure (poster)

W Cañón Montañez; 143

Nursing staff allocation and patient outcomes in ICU (poster)

K Grillo Padilha, S Bento, K Mourek, K

Colbert; 155
Observing the weaning of long-term ventilated patients in ICU C Kydonaki; 159

Open ICU: the experience of Santa Maria Annunziata Hospital

L Matteucci, L Corsini, S Gori, C Nocentini, E Prosperi; 162

Open ICU versus closed ICU R Oggioni, A Bencivinni, S Niccoli, A Giachetta; 165

Out-of-hospital cardiac arrest in a medical center in Taiwan: an observational study (poster) L Min-Ling; 163

$\mathbf{P}$

Patient hygiene in the ICU: a descriptive study of bed-bathing practice (poster) F Coyer, J O'Sullivan, N Cadman; 149

Patients' experience of pain after cardiac surgery: pain definitions, procedures that cause the most and relieve the most pain (poster)

F Eti Aslan, A Badir, S Karadag Arli, F Demir, H Cakmakci; 151

Pattern recognition of culture and psycho-social information in a PICU (poster)

LM Vivian, CR Swanepoel, V Burch, AC Argent; 179

Perceived impact of stress on cognition and performance in ICU nurses J Perry, R Endacott, K Page; 168

Perceived work stress level and underlying stressors among Indian critical care nurses (poster)

J Vati, R Sharma, S Sachdeva; 178

Phenomenological analysis of the experience of implementation of an automatic defibrillator

JM Cachon, D Palacios, C Alvarez; 142

Planned nursing care decreases morbid complication and may increases the patient satisfaction (poster)

A Yava, A Koyuncu, F Koyuncu, H Cicek, N Tosun; 181

Postoperative pain and patients' needs for pain management after cardiac surgery (poster)

A Yava, A Koyuncu; 180
Presence of stress at nurses in work with critically ill patients (poster) P Mirkovic, G Dragosev, G Kukolj, S Alijevic; 163

Pressure ulcers in ICU: relation between pressure ulcer risk, patient severity and nursing workload

ML Pedreira, F Wenzel, M Cremasco, S Zanei, I Whitaker; 168

Principles ethics and intensive nurse care

JM Cachon, C Alvarez, D Palacios; 143

Professional autonomy, collaboration and moral distress among European ICU Nurses

E Papathanassoglou, M Kalafati, M Karanikola, J Albarran; 167

Prolonged cardiopulmonary resuscitation process and lower frequency of medicare staff visit independ

J Tsai; 177

Proposal for introduction Richmond Agitation Sedation Scale

T Cividini; 148

Proposal of socio-educational center specialized in reorganization after disasters (poster)

E Zampier, CE Stange, AS Sales; 183

Psychological support and coronary heart disease patients outcomes

A Spirou, Z Aggelopoulou, E

Papathanassoglou; 176

Psychophysiological ventilator weaning model (PVWM): a model testing Y Chen, AH Davis; 146

$\mathbf{R}$

Reducing the rate of central catheter infection in ICU: a review of healthcare failure (poster)

J Tsai; 177

Relatives' experiences of caring for patients at home following a critical illness

C Plowright; 169

Research on nursing basic ability (poster)

C Chu-Ling; 146

Resource nursing in critical care V Leon, A Lyons, K Marine; 161 


\section{* Abstracts title index *}

Results of nursing interventions in coronary ICU: a pilot study (poster) S Balci, O Yazici Korkmaz, S Abali; 140

Rostering complexities: using videoreflexivity to facilitate understanding between managers and nursing staff K Carroll; 143

S

Singapore volunteers overseas project: a 3-year train-the-trainers programme in paediatric ICU (poster)

SK Lee, NL Pang, LL Ong; 160

Slipping into SLEDD (sustained lowefficiency daily dialysis)

L Nusdorfer, V Godfrey; 165

Stress peptide levels and lymphocyte apoptosis in critical illness (poster) E Papathanassoglou, M Mpouzika, M Giannakopoulou, E Bozas, S Mpoti, A Karabinis; 167

$\mathbf{T}$

Taking critical care outside

C Plowright; 169

The care of delirium given by ICU Nurses (poster)

S Ito; 157

The comparison research on the learning level of nursing senior students about interpreting ECG in T

H Bana Derakhshan; 140

The distribution of the diagnosis of acute coronary syndrome according to the socio-economic condition

S Abali, O Yazici Korkmaz, S Balci, H Aydemir; 138

The effect of discharge instructions on the return to functional abilities of stroke patients (poster)

F Aganon, AR Conde; 138

The efficacy of bright light therapy in the peri-operative period for the prevention of delirium (poster)

T Taguchi, S Nishioka, M Nakamori, T Wakayama, K Kashiwabara, R Taneike; 176
The future is here! Simulation + e learning $=$ accessible education for critical care nurses everywhere S Goldsworthy, L Graham, J Bennett, S Sproul, J Rush; 154

The impact of nursing rounds on patient care (poster)

L Aitken, S Clayton, E Burmeister; 139

The oxygen supply and demand framework: a tool to support integrative learning (poster)

E Shackell, M Gillespie; 174

The patient's clinical documentation in the ICU of Treviso

L Gambirasi; 154

The prediction and prevention of arrhythmias in acute inferior MI and nursing care with an interesting ECG (poster)

MT Sareban; 173

The role of nursing workload on glycemic control (poster)

C Quirós Herranz, S Garcia Gomez, M Martinez Lareo, I Cerrillo Gonzalez, G Rollan Rodriguez, A Jara Perez, R Alameda Varela, FJ Carmona Monge; 170

The role of the preoperative anxiety on delirium after open heart surgery A Yava, A Koyuncu, F Koyuncu; 181

The use of standing orders and authorised prescribing by a critical care outreach nurse practitioner A Pirret; 169

The "zassi bowel management system": a healing accelerator of the perineum burn wound

I Menachem, A Mayo, Y Barlavie, Y Ulman, M Sabag; 162

Transfusion-related acute lung injury and nursing care

V Bracko, D Satosek, B Juvan, Z Nagode; 142

U

Ultrasound-guided percutaneous arterial puncture in children: a randomized controlled study (poster) ML Pedreira, CB Franco, MA Peterlini; 168
Unidentified viral haemorrhagic fever in the critical care setting

A Hayward, N Sewlall, WJ Erasmus, J Erasmus; 155

Use of bedside inhaled anaesthetics for status asthmaticus in Kartagener E Casey; 144

Use of computerized patient database and learning environment to promote evidence based nursing (poster) E Valovirta, A Lappalainen, J Kotila; 177

Utility and feasiblity of mobile wound care documentation tool in the management of pressure ulcers (poster) L Nusdorfer, P Rowan, I Macleod, H Krieber; 166

Utilized information system to reduce the medication errors (poster) L Wei, W Cheng; 179

W

What is the state of the art in drug surveillance in the ICU? Pharmacovigilance (poster) E Siviero; 175

Why patients don't want to be transferred from ICU: nurses' perspectives (poster)

H Cicek, A Demirtas, A Yava, N Tosun, N Akbayrak; 147

\section{ITALIAN ABSTRACTS}

\section{C}

Confronto randomizzato Abbocath vs cateteri Midline in pazienti in terapia ev per almeno 6 Giorni

A Mitidieri; 184

Cure di fine vita: contesto italiano N Marinelli; 184

T

The nurse coordinator transplants, risk management

D Zambello, L Libanori, B Zambello, I

Crepaldi, M Sommacampagna; 184 